\title{
HIV related pulmonary arterial hypertension: epidemiology in Africa, physiopathology, and role of antiretroviral treatment
}

\author{
Jean Joel R. Bigna ${ }^{1 *}$, Paule Sandra D. Sime ${ }^{2}$ and Sinata Koulla-Shiro ${ }^{2,3}$
}

\begin{abstract}
The development of HIV related pulmonary arterial hypertension (PAH) reduces the probability of survival by half as compared with HIV-infected individuals without HIV related PAH. HIV infected patients have a greater incidence of PAH compared to general population and have a 2500 -fold increased risk of developing PAH. It is therefore important to have a recent overview of the problem in Africa, the most HIV affected part of the world (70 \% of all HIV infection in the world). First, we discussed the epidemiology of HIV-related PAH in Africa. Second, the current understanding of the HIV-related PAH pathogenesis has been covered. Third, role of highly active antiretroviral therapy on HIV-related PAH has been revisited. There are few data concerning epidemiology of HIV related pulmonary hypertension in Africa leading to necessity to conduct further prospective large studies. The prevalence of PAH among HIV infected people in Africa varies from 5 to $13 \%$. The prevalence of HIV-related PAH in Africa is notably high compared to those in developed countries and in general population. The pathogenesis of PAH is clearly complex, and probably results from the interaction of multiple modulating genes with environmental factors. The physiopathology includes cytokines secretion increase which induces dysregulation of endothelial and vascular smooth muscle cell growth and imbalance of endogenous vasodilators and constrictors; HIV viral proteins which induces vascular oxidative stress, smooth myocyte proliferation and migration, and endothelial injury and genetic predisposition due to some major histocompatibility complex alleles, particularly HDL-DR6 and HLA-DR5. Histologically, HIV related PAH has the same characteristics with other types PAH. Antiretroviral therapy have a beneficial effect on the outcome of HIV related pulmonary hypertension, but it lacks evidence from large prospective studies.
\end{abstract}

Keywords: HIV, AIDS, Pulmonary hypertension, Pulmonary arterial hypertension, Africa, Antiretroviral therapy

\section{Background}

Pulmonary hypertension $(\mathrm{PH})$ is defined as mean pulmonary arterial pressure (mPAP) $\geq 25 \mathrm{mmHg}$ on right heart catheterization at rest [1]. The classification of $\mathrm{PH}$ involves five groups: pulmonary arterial hypertension (PAH) which includes human immunodeficiency virus (HIV) related $\mathrm{PH}, \mathrm{PH}$ due to left heart diseases,

\footnotetext{
*Correspondence: bignarimjj@yahoo.fr

1 Department of Epidemiology and Public Health, Pasteur Center of Cameroon Member of International Network of the Pasteur Institutes, Yaoundé, Cameroon

Full list of author information is available at the end of the article
}

$\mathrm{PH}$ due to respiratory diseases and/or hypoxemia, $\mathrm{PH}$ due to chronic embolic disease, and $\mathrm{PH}$ having unclear multifactorial mechanism [1]. PAH is defined by a $\mathrm{mPAP} \geq 25 \mathrm{mmHg}$, pulmonary capillary wedge pressure $\leq 15 \mathrm{mmHg}$ and pulmonary vascular resistance $>3$ Wood units at the time of right heart catheterization [1].

Symptoms result from right ventricular dysfunction. The first clinical manifestation is effort intolerance and exertional dyspnea that will progress to the point of breathlessness at rest. These symptoms are nonspecific, of course, and overlap with those of many other diseases, including pulmonary and cardiac conditions. Echocardiography is an extremely useful tool for the diagnosis of 
HIV related PAH, and Doppler echocardiography can be used to estimate systolic pulmonary artery pressure. Assessment of hemodynamic measures by catheterization remains, however, the best test for evaluating the response to therapy. Cardiac catheterization is mandatory to definitively diagnose the disease and exclude any underlying cardiac shunt as the etiology [2].

About two-thirds of the deaths in patients with HIVrelated PAH were due to the consequences of $\mathrm{PAH}$, such as right heart failure, cardiogenic shock, and sudden death [3]. HIV infected patients have a greater incidence of $\mathrm{PH}$ compared to general population [4]. In comparison with the incidence of idiopathic PAH in the general population (1-2 per million), HIV-infected patients have a 2500-fold increased risk of developing PAH [5]. The development of HIV related PAH reduces the probability of survival by half as compared with HIV infected individuals without HIV related PAH. It therefore is important to have a recent overview of the problem in sub-Saharan Africa, the most HIV affected part of the world with 24.7 million people living with HIV (70 \% of all the world) [6], and to summarize current knowledge on HIV-related PAH.

First, we discussed the epidemiology of HIV-related PAH in Africa. Second, the current understanding of the HIV-related PAH pathogenesis has been covered. Third, role of highly active antiretroviral therapy on HIV-related PAH has been revisited.

\section{Epidemiology of HIV related pulmonary arterial hypertension in Africa}

There are few data concerning epidemiology of HIV related pulmonary hypertension in Africa which come all from cross-sectional studies (Table 1). A study conducted in 2012 including 116 vertically HIV-infected adolescents (10-19 years) in Zimbabwe revealed a prevalence of $7 \%$ for PAH [7]. In another study including $102 \mathrm{HIV}$ infected patients in Tanzania, pulmonary hypertension was present among $13 \%$ of patients [8]. In a retrospective cross-sectional study conducted in Burkina-Faso among 79 HIV-infected patients, the prevalence was $5 \%$ [9]. In a cross sectional study in South Africa including 518 HIVinfected patients, the prevalence was $8 \%$ [10].

The prevalence of PH among HIV infected people in Africa varies from 5 to $13 \%$. With around 24.7 million of HIV infected people in sub-Saharan Africa [6], between 1.2 and 3.2 million might have PAH. There is no difference between the prevalence in male (6-19\%) and the prevalence in female (around $10 \%$ ). The prevalence in sub-Saharan Africa is notably high compared to those in developed countries where the prevalence is close to $0.5 \%[4,11-13]$. The possible explanation is that, the diagnosis and the management of HIV infection were made at an advanced stage of HIV disease. And also, in most developed countries, antiretroviral therapy is initiated regardless CD4 count and HIV infection clinical stage compared to developing countries which take in account these parameters.

There is need for large prospective studies to better estimate burden of HIV related PAH in Africa. In all of the studies mentioned above, the diagnostic tool was echocardiography, therefore there is need studies using cardiac catheterization which gold standard [2] to better estimate epidemiology. As demonstrated by a study, echocardiographic assessment of pulmonary arterial pressure was inaccurate in $19.7 \%$ of patients compared to right heart catheterization [14].

\section{Physiopathology of HIV related pulmonary hypertension}

The pathogenesis of PAH is clearly complex, and probably results from the interaction of multiple modulating genes with environmental factors. The mechanism is unclear and to date not completely understood. Several key aspects involved in the pathophysiological process of HIV related PAH. HIV infection itself plays a major role in the development of PAH. The mechanism is not directly due to the action of the virus because attempts to localize the virus in the vascular lesions or endothelial cells of affected patients have been unsuccessful [15], suggesting that a direct role of the virus is unlikely, and indicating that the underlying mechanism in pulmonary arterial hypertension associated with HIV is related to the indirect action of infection, possibly through the action of viral proteins and chronic inflammation cytokines mediated due to HIV infection. Three main mechanisms are responsible for the HIV PAH: the HIV viral proteins found in the pulmonary vascular endothelium, cytokines due to the presence of HIV and increase the genetic predisposition due to HIV (Fig. 1). The pathogenesis of PAH is characterized by three major processes including vasoconstriction, vascular remodeling and microthrombotic events [16].

\section{Role of cytokines and inflammation}

HIV infection induces high secretion of some cytokines by monocytes, macrophages and lymphocytes including interleukin (IL)-1, IL-6, IL8, IL-13, tumor necrosis factor (TNF) $\alpha$ and platelet-derived growth factors which can exacerbates a patent PAH or induces inflammation of vascular endothelium leading to PAH [16-23]. The activation of platelet derived growth factor [24] and vascular endothelial pathway [25] can result to aberrant pulmonary vascular activity. These growth factors and cytokines can lead to dysregulation of endothelial and vascular smooth muscle cell growth and imbalance of endogenous 


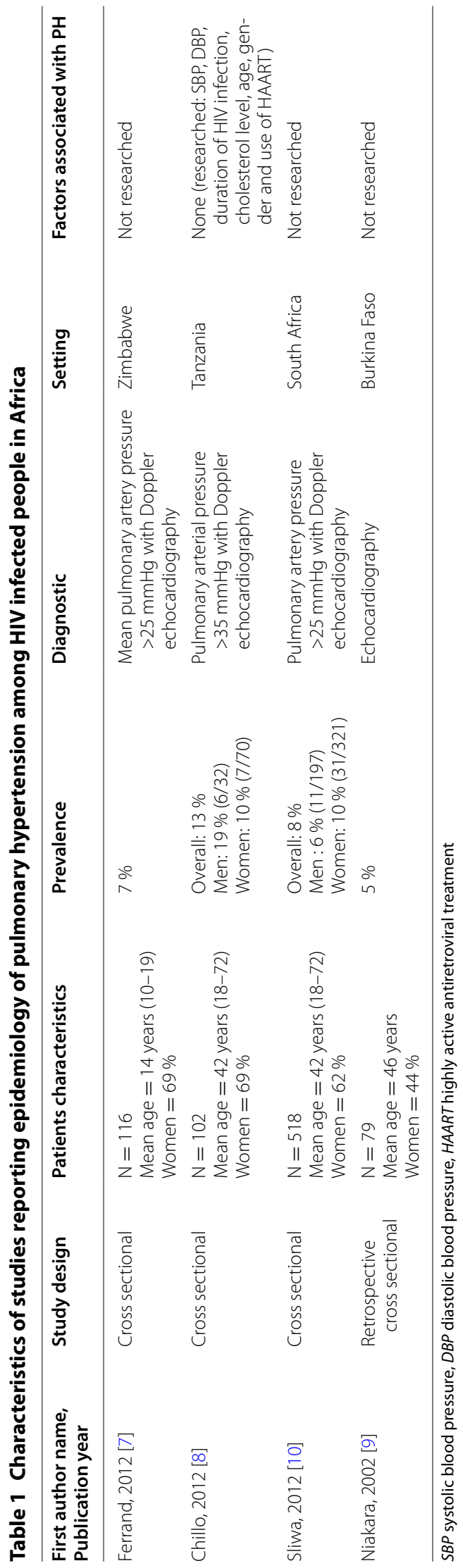




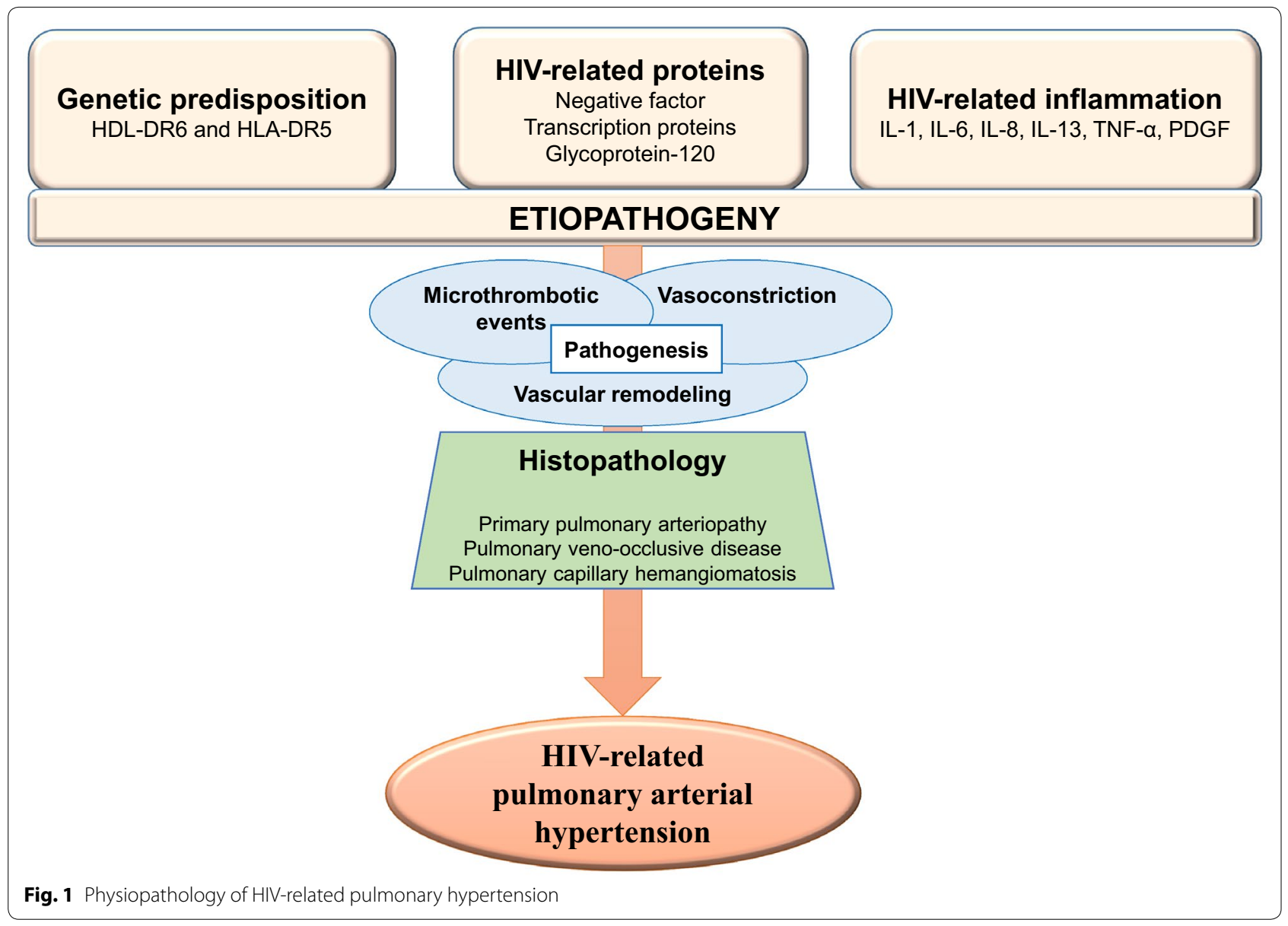

vasodilators and constrictors (in favor of constrictors). IL-1 appears to have deleterious effects for the development and progression of pulmonary hypertension. The exact mechanisms, however, remain unclear [16]. It was shown that elevated levels of IL-6 resulted in an upregulation of vascular endothelial growth factor receptor II and matrix metalloproteinase-9, an endopeptidase that promotes angiogenesis through regulation of cell attachment, proliferation, and migration $[16,26]$. IL- 8 is thought to play an important role in the development of $\mathrm{PAH}$, especially in early phases of vascular remodeling. IL-8 is known to have proangiogenic and antiapoptotic activities and acts as a growth factor for endothelial cells [27]. IL-13 acts as an important mediator of cell proliferation and tissue remodeling in lungs [28]. This is explain by imbalance of NO homeostasis and increased muscularization of pulmonary arteries [16]. Similarly to other inflammatory cytokines, elevated serum levels of TNF- $\alpha$ were described in PAH patients. TNF- $\alpha$ might play an important role in the development of pulmonary hypertension, even though the concrete mechanisms remain unknown [29]. Interestingly some studies show that
TNF- $\alpha$ blockers ameliorate pulmonary pressure, while other studies found no significant effects [16].

\section{Role of HIV viral proteins}

These HIV viral proteins include negative factor (Nef), transcription proteins (Tat) and glycoprotein 120 (gp120) [30-35]. These proteins probably induce vascular oxidative stress, smooth myocyte proliferation and migration, and endothelial injury leading to HIV related PAH.

Nef induces complex plexiform lesion in the pulmonary vasculature, this has been demonstrated in a study comparing macaque Nef-positive simian immunodeficiency virus (SIV) and macaque Nef-negative SIV [30]. The involvement of Nef in the occurrence of HIV-related PAH has been also demonstrated in porcine model study and among HIV infected persons [31, 33], because Nef is present in the endothelial cells of HIV infected patients with PAH. Nef can enter into the pulmonary endothelial cells via the CXCR 4 receptor and therefore induce proliferation and apoptosis of endothelial cells in lung $[36,37]$. Thus, localization of Nef to the lipid rafts may 
be sufficient to trigger the changes associated with the endothelial cell expansion characteristic of plexiform lesions [38].

Bone morphogenetic protein type II receptor (BMPR2) participate in a multiplicity of ways in the regulation of numerous physiological and pathological processes including the inhibition of the proliferation of vascular smooth muscle tissue by promoting the survival of pulmonary arterial endothelial cells, therefore preventing arterial damage and adverse inflammatory responses [39]. Its wide-ranging biological functions is controlled by several mechanisms, including regulation of transcription, complex formation among the signaling receptors (oligomerization) and with co-receptors, binding of the receptors to scaffolding proteins or their targeting to specific membrane domains [39]. This control can be breakdown by a mutation the gene encoding to the BMPR2. A heterozygous germline mutations in the gene encoding the BMPR2), can lead to heritable PAH in more than $70 \%$ of cases [40-42]. Tat represses transcription of gene encoding to BMPR2 in monocytes, suggesting that Tat-mediated reduction of BMPR2 may be linked to the development of HIV related PAH [43]. The BMPR2 is a member of the transforming growth factor-beta receptor family and is expressed on the surface of several cell types including endothelial cells and macrophages. The modulation of host gene transcription by HIV infection might genetically alter expression of BMPR2. As the HIV Tat protein is the major transcriptional regulator of host gene expression during HIV infection, Tat downregulates BMPR2 expression and signaling by half. This level of decreased BMPR2 expression can lead to abnormal pulmonary vascular function with exuberant cellular proliferation [43]. Tat enhance the activity of vascular endothelial cells via interleukin-6 [44].

Secreted HIV gp120 proteins induce lung endothelial cell injury and could contribute to the development of HIV-related PAH. The mechanism is by apoptosis and smooth cell proliferation due to exposure of HIV-1 gp120 proteins to primary human lung microvascular endothelial cells [32]. Gp120 also significantly increases secretion of the potent vasoconstrictor endothelin-1 by human lung endothelial cells [45].

Nevertheless, it is essential to state that only a small proportion of infected patients with HIV will develop HIV related PAH. Other factors, including stage of immune depression, likely play a role in the occurrence of the HIV related PAH. It is possible that, the implication of HIV viral proteins be related with high level HIV-RNA, because detectable plasma HIV-RNA is associated with the risk to develop PAH, as demonstrated in a cross-sectional study $[11,46]$. This can also explain why the prevalence of HIV-related PAH is high in Africa compared to developed countries, because HIV-infected patients in Africa have more HIV infection control failure compared to those in developed countries. The occurrence of pulmonary arterial hypertension is independent of the CD4 cell count, but it appears to be related to the duration of HIV infection [47].

\section{Role of genetic predisposition}

Not all HIV infected develop PAH. Genetic predisposition plays a key role in the development of PAH among HIV infected people. Some major histocompatibility complex alleles have been incriminated by their high prevalence among HIV infected people with PAH, particularly HDL-DR6 and HLA-DR5 [48, 49].

It appears that the mechanism mainly specific to HIVrelated PAH is due to viral proteins. Other mechanisms of HIV-related PAH are associated to either an increase in genetic predisposition or to an increase in the serum level of cytokines involved in the PAH.

\section{Histopathology}

Histologically, HIV related PAH has the same characteristics with other types PAH [50]. There are three histopathological presentation including primary pulmonary arteriopathy (plexiform arteriopathy, thrombotic arteriopathy, isolated medial hypertrophy, and medial hypertrophy with intimal fibrosis), pulmonary veno-occlusive disease, and pulmonary capillary hemangiomatosis [51]. Concerning the importance of form, the most common histological form of HIV related PAH is the plexogenic pulmonary arteriopathy followed by thrombotic pulmonary arteriopathy, pulmonary medial hypertrophy with intimal fibrosis, and pulmonary veno-occlusive disease [50].

\section{Role of antiretroviral therapy in the treatment of HIV related pulmonary hypertension}

There is no cure for pulmonary arterial hypertension [47]. It is essential to note that the treatment of HIVrelated PAH is similar to the treatment of other forms of PAH. Several medications may be adjunctively (non-specific therapies) used in the management of PAH depending on the clinical presentation of PAH. These include: (1) anticoagulants because PAH patients are at risk for small intrapulmonary thrombus due to prothrombotic state, sedentary lifestyle, and cardiac dilation [22, 52]; (2) supplemental oxygen because patients with PAH often develop hypoxemia which can further exacerbate pulmonary arterial vasoconstriction [22, 52]; (3) diuretic agents which can be used in the case of volume overloaded; Digoxin in the case right sided heart failure [22, 52]; (4) Calcium channel blocker among PAH patients who develop decrease in mPAP between $10 \mathrm{mmHg}$ and 
$40 \mathrm{mmHg}$. This reduction in mPAP must be accompanied by improved or at least unchanged cardiac output and unchanged or minimally reduced systemic blood pressure [22, 52, 53].

Several medicines are available in the specific management of PAH, the same both for non HIV-related PAH and HIV-related PAH, such as endothelin receptor antagonists, prostaglandin analogs, and phosphodiesterase 5 inhibitors [52].

There have been no large prospective studies of the effects of antiretroviral treatment on HIV related PAH. Most of the studies demonstrated the beneficial effect of the use of highly active antiretroviral therapy (HAART) among HIV infected patients with PAH on their outcome. As demonstrated in a cross sectional study, detectable plasma HIV-RNA was associated with the risk to develop PAH [11]. This suggests that the use of HAART, whose aim is to prevent the multiplication of HIV and thus make undetectable viral load; could reduce the risk of developing PAH in patients infected with HIV. In a prospective cohort study [54], highly active antiretroviral therapy (HAART) improved pulmonary artery pressure in HIV/ AIDS patients if instituted at early stages (WHO classes I and II). However, at more advanced stages of pulmonary artery hypertension, it does not have any significant effect on reduction of the same. In the view of these results, early detection of PAH in HIV/AIDS patients is essential and prompt institution of HAART should be considered in them even when those patients do not fulfill the conventional criteria for initiation of this treatment. Further studies was needed to investigate these possibility. HAART should not be used as a sole therapy for HIV-related PAH, and the initiation of PAH-specific therapy is of paramount importance. HAART only ameliorate the outcome of patients with HIV-related PAH. In a cross-sectional study including $400 \mathrm{HIV}$ infected patients, a current use of Tenofovir was associated with lower PAH prevalence [55]. Several other studies also show the beneficial effect of the use of HAART in the treatment of PAH [56, 57]. HAART also reduce mortality [58] and cardiac involvement [59] among HIV infected patients with PAH. Therefore, it is necessary that all patients with HIV-related PAH start HAART regardless HIV disease clinical stage and CD4 count. However, it is necessary to conduct large prospective studies to better estimate the effect of HAART on PAH.

\section{Conclusions}

There is a high prevalence of PAH in patients infected with HIV in Africa, although there are very few studies, hence the need for further studies including research also risk factors. This prevalence is very high compared to that in the developed countries and compared with that in the general population. The pathophysiologic mechanism responsible for PAH in subjects infected with HIV remains to be explored. One notes nevertheless the involvement of HIV viral proteins, cytokines and genetic predisposition in the pathophysiologic mechanism. Although the pathophysiological mechanism of HIV-related PAH is different from other $\mathrm{PAH}$, histological presentation is the same. The beneficial role of antiretroviral drugs in the treatment of PAH associated with HIV is not yet established, which requires large prospective studies to clarify.

\section{Abbreviations}

BMPR2: bone morphogenic protein receptor 2; Gp120: glycoprotein 120; HAART: highly active antiretroviral therapy; HIV: human immunodeficiency virus; Nef: negative factor; PAH: pulmonary arterial hypertension; PH: pulmonary hypertension; SIV: simian immunodeficiency virus; Tat: transcription proteins.

\section{Authors' contributions}

JJRB conceived and designed the study, and drafted manuscript. PSDS and SK-S conceived and designed the study, and revised manuscript for important intellectual content. All authors read and approved the final manuscript.

\section{Author details}

${ }^{1}$ Department of Epidemiology and Public Health, Pasteur Center of Cameroon Member of International Network of the Pasteur Institutes, Yaoundé, Cameroon. ${ }^{2}$ Faculty of Medicine and Biomedical Sciences, University of Yaoundé 1, Yaoundé, Cameroon. ${ }^{3}$ Infectious Diseases Unit, Yaoundé Central Hospital, Yaoundé, Cameroon.

\section{Acknowledgements}

This paper needed no particular funding.

\section{Competing interests}

The authors declare that they have no competing interests.

Received: 19 May 2015 Accepted: 29 October 2015

Published online: 11 November 2015

\section{References}

1. Simonneau G, Gatzoulis MA, Adatia I, Celermajer D, Denton C, Ghofrani A, GomezSanchez MA, KrishnaKumar R, Landzberg M, Machado RF, et al. Updated clinical classification of pulmonary hypertension. J Am Col Cardiol. 2013;62(25 Suppl):D34-41

2. Cicalini S, Almodovar S, Grilli E, Flores S. Pulmonary hypertension and human immunodeficiency virus infection: epidemiology, pathogenesis, and clinical approach. Clin microbiol Infect Off Publ Eur Soc Clin Microbiol Infect Dis. 2011;17(1):25-33.

3. Opravil M, Pechere M, Speich R, Joller-Jemelka HI, Jenni R, Russi EW, Hirschel B, Luthy R. HIV-associated primary pulmonary hypertension. A case control study. Swiss HIV Cohort Study. Am J Respir Crit Care Med. 1997;155(3):990-5.

4. Crothers K, Huang L, Goulet JL, Goetz MB, Brown ST, Rodriguez-Barradas MC, Oursler KK, Rimland D, Gibert CL, Butt AA, et al. HIV infection and risk for incident pulmonary diseases in the combination antiretroviral therapy era. Am J Respir Crit Care Med. 2011;183(3):388-95.

5. Correale M, Palmiotti GA, Lo Storto MM, Montrone D, Foschino Barbaro MP, Di Biase M, Lacedonia D. HIV-associated pulmonary arterial hypertension: from bedside to the future. Eur J Clin Invest. 2015;45(5):515-28.

6. Global statistics [http://www.unaids.org/sites/default/files/ media_asset/20140716_FactSheet_en.pdf].

7. Ferrand RA, Desai SR, Hopkins C, Elston CM, Copley SJ, Nathoo K, Ndhlovu CE, Munyati S, Barker RD, Miller RF, et al. Chronic lung disease in adolescents with delayed diagnosis of vertically acquired HIV infection. Clin Infect Dis Off Publ Infect Dis Soc Am. 2012;55(1):145-52. 
8. Chillo P, Bakari M, Lwakatare J. Echocardiographic diagnoses in HIV-infected patients presenting with cardiac symptoms at Muhimbili National Hospital in Dar es Salaam, Tanzania. Cardiovas J Africa. 2012;23(2):90-7.

9. Niakara A, Drabo YJ, Kambire Y, Nebie LVA, Kabore NJP, Simon F. Cardiovascular diseases and HIV infection: a study of 79 cases in the national hospital of Ouagadougou (Burkina Faso). Bull Soc Pathol Exot. 2002;95(1):23-6.

10. Sliwa K, Carrington MJ, Becker A, Thienemann F, Ntsekhe M, Stewart S. Contribution of the human immunodeficiency virus/acquired immunodeficiency syndrome epidemic to de novo presentations of heart disease in the Heart of Soweto Study cohort. Eur Heart J. 2012;33(7):866-74.

11. Quezada M, Martin-Carbonero L, Soriano V, Vispo E, Valencia E, Moreno V, de Isla LP, Lennie V, Almeria C, Zamorano JL. Prevalence and risk factors associated with pulmonary hypertension in HIV-infected patients on regular follow-up. AIDS. 2012;26(11):1387-92

12. Speich R, Jenni R, Opravil M, Pfab M, Russi EW. Primary pulmonary hypertension in HIV infection. Chest. 1991;100(5):1268-71.

13. Sitbon O, Lascoux-Combe C, Delfraissy JF, Yeni PG, Raffi F, De Zuttere D, Gressin V, Clerson P, Sereni D, Simonneau G. Prevalence of HIV-related pulmonary arterial hypertension in the current antiretroviral therapy era. Am J Respir Crit Care Med. 2008;177(1):108-13.

14. Selby VN, Scherzer R, Barnett CF, MacGregor JS, Morelli J, Donovan C, Deeks SG, Martin JN, Hsue PY. Doppler echocardiography does not accurately estimate pulmonary artery systolic pressure in HIV-infected patients. AIDS. 2012;26(15):1967-9.

15. Mette SA, Palevsky HI, Pietra GG, Williams TM, Bruder E, Prestipino AJ, Patrick AM, Wirth JA. Primary pulmonary hypertension in association with human immunodeficiency virus infection. A possible viral etiology for some forms of hypertensive pulmonary arteriopathy. Am Rev Respir Dis. 1992;145(5):1196-200

16. Groth A, Vrugt B, Brock M, Speich R, Ulrich S, Huber LC. Inflammatory cytokines in pulmonary hypertension. Respir Res. 2014;15:47.

17. Pellicelli AM, Palmieri F, Cicalini S, Petrosillo N. Pathogenesis of HIV-related pulmonary hypertension. Ann NY Acad Sci. 2001;946:82-94.

18. Aliyu ZY, Kato GJ, Taylor Jt, Babadoko A, Mamman Al, Gordeuk VR, Gladwin MT. Sickle cell disease and pulmonary hypertension in Africa: a global perspective and review of epidemiology, pathophysiology, and management. Am J Hematol. 2008;83(1):63-70.

19. Olivetta E, Percario Z, Fiorucci G, Mattia G, Schiavoni I, Dennis C, Jager J, Harris M, Romeo G, Affabris E, et al. HIV-1 Nef induces the release of inflammatory factors from human monocyte/macrophages: involvement of Nef endocytotic signals and NF-kappa B activation. J Immunol. 2003;170(4):1716-27.

20. Dai HL, Zhang M, Xiao ZC, Guang XF, Yin XL. Pulmonary arterial hypertension in HIV infection: a concise review. Heart, Lung Circ. 2014;23(4):299-302.

21. Pellicelli AM, D'Ambrosio C, Vizza CD, Borgia MC, Tanzi P, Pino P, Zachara E, Soccorsi F. HIV-related pulmonary hypertension. From pathogenesis to clinical aspects. Acta Cardiol. 2004;59(3):323-30.

22. Mirrakhimov AE, Ali AM, Barbaryan A, Prueksaritanond S. Human immunodeficiency virus and pulmonary arterial hypertension. ISRN cardiology. 2013;2013:903454.

23. Tcherakian C, Couderc L, Humbert M, Godot V, Sitbon O, Devillier P. Inflammatory mechanisms in HIV-associated pulmonary arterial hypertension. Sem Resp Critic Care Med. 2013;34(5):645-53.

24. Petitpretz P, Brenot F, Azarian R, Parent F, Rain B, Herve P, Simonneau G. Pulmonary hypertension in patients with human immunodeficiency virus infection. Comparison with primary pulmonary hypertension. Circulation. 1994;89(6):2722-7.

25. Ascherl G, Hohenadl C, Schatz O, Shumay E, Bogner J, Eckhart L, Tschachler E, Monini P, Ensoli B, Sturzl M. Infection with human immunodeficiency virus-1 increases expression of vascular endothelial cell growth factor in T cells: implications for acquired immunodeficiency syndromeassociated vasculopathy. Blood. 1999;93(12):4232-41.

26. Steiner MK, Syrkina OL, Kolliputi N, Mark EJ, Hales CA, Waxman AB. Interleukin-6 overexpression induces pulmonary hypertension. Circ Res. 2009;104(2):236-44 (228p following 244)

27. Li A, Varney ML, Valasek J, Godfrey M, Dave BJ, Singh RK. Autocrine role of interleukin-8 in induction of endothelial cell proliferation, survival, migration and MMP-2 production and angiogenesis. Angiogenesis. 2005:8(1):63-71.
28. Wynn TA. Fibrotic disease and the $T(H) 1 / T(H) 2$ paradigm. Nat Rev Immunol. 2004;4(8):583-94.

29. Soon E, Holmes AM, Treacy CM, Doughty NJ, Southgate L, Machado RD, Trembath RC, Jennings S, Barker L, Nicklin P, et al. Elevated levels of inflammatory cytokines predict survival in idiopathic and familial pulmonary arterial hypertension. Circulation. 2010;122(9):920-7.

30. Marecki JC, Cool CD, Parr JE, Beckey VE, Luciw PA, Tarantal AF, Carville A, Shannon RP, Cota-Gomez A, Tuder RM, et al. HIV-1 Nef is associated with complex pulmonary vascular lesions in SHIV-nef-infected macaques. Am J Respir Crit Care Med. 2006;174(4):437-45.

31. Voelkel NF, Cool CD, Flores S. From viral infection to pulmonary arterial hypertension: a role for viral proteins? AIDS. 2008;22(Suppl 3):S49-53.

32. Kanmogne GD, Primeaux C, Grammas P. Induction of apoptosis and endothelin-1 secretion in primary human lung endothelial cells by HIV-1 gp120 proteins. Biochem Biophys Res Commun. 2005;333(4):1107-15.

33. Duffy $P$, Wang $X$, Lin PH, Yao Q, Chen C. HIV Nef protein causes endothelial dysfunction in porcine pulmonary arteries and human pulmonary artery endothelial cells. J Surg Res. 2009;156(2):257-64.

34. Rusnati M, Presta M. HIV-1 Tat protein and endothelium: from protein/cell interaction to AIDS-associated pathologies. Angiogenesis. 2002;5(3):141-51.

35. Mermis J, Gu H, Xue B, Li F, Tawfik O, Buch S, Bartolome S, O'Brien-Ladner A, Dhillon NK. Hypoxia-inducible factor-1 alpha/platelet derived growth factor axis in HIV-associated pulmonary vascular remodeling. Respir Res. 2011;12:103.

36. James CO, Huang MB, Khan M, Garcia-Barrio M, Powell MD, Bond VC Extracellular Nef protein targets CD4+ T cells for apoptosis by interacting with CXCR4 surface receptors. J Virol. 2004;78(6):3099-109.

37. Choi HJ, Smithgall TE. HIV-1 Nef promotes survival of TF-1 macrophages by inducing $\mathrm{BCl}-\mathrm{XL}$ expression in an extracellular signal-regulated kinasedependent manner. J Biol Chem. 2004;279(49):51688-96.

38. Tuder RM, Marecki JC, Richter A, Fijalkowska I, Flores S. Pathology of pulmonary hypertension. Clin Chest Med. 2007;28(1):23-42.

39. Ehrlich M, Gutman O, Knaus P, Henis YI. Oligomeric interactions of TGFbeta and BMP receptors. FEBS Lett. 2012:586(14):1885-96.

40. Soubrier F, Chung WK, Machado R, Grunig E, Aldred M, Geraci M, Loyd JE, Elliott CG, Trembath RC, Newman JH, et al. Genetics and genomics of pulmonary arterial hypertension. J Am Coll Cardiol. 2013;62(25 Suppl):D13-21.

41. Li W, Dunmore BJ, Morrell NW. Bone morphogenetic protein type II receptor mutations causing protein misfolding in heritable pulmonary arterial hypertension. Proc Am Thorac Soc. 2010;7(6):395-8.

42. Austin ED, Loyd JE, Phillips JA 3rd. Genetics of pulmonary arterial hypertension. Sem Resp Critic Care Med. 2009;30(4):386-98.

43. Caldwell RL, Gadipatti R, Lane KB, Shepherd VL. HIV-1 TAT represses transcription of the bone morphogenic protein receptor-2 in U937 monocytic cells. J Leukoc Biol. 2006;79(1):192-201.

44. Hofman FM, Wright AD, Dohadwala MM, Wong-Staal F, Walker SM Exogenous tat protein activates human endothelial cells. Blood. 1993;82(9):2774-80.

45. Ehrenreich H, Rieckmann P, Sinowatz F, Weih KA, Arthur LO, Goebel FD, Burd PR, Coligan JE, Clouse KA. Potent stimulation of monocytic endothelin-1 production by HIV-1 glycoprotein 120. J Immunol. 1993;150(10):4601-9.

46. Degano B, Guillaume M, Savale L, Montani D, Jais X, Yaici A, Le Pavec J, Humbert M, Simonneau G, Sitbon O. HIV-associated pulmonary arterial hypertension: survival and prognostic factors in the modern therapeutic era. AIDS. 2010;24(1):67-75.

47. Farber HW, Loscalzo J. Pulmonary arterial hypertension. N Engl J Med. 2004;351(16):1655-65.

48. Morse JH, Barst RJ, Itescu S, Flaster ER, Sinha G, Zhang Y, Fotino M. Primary pulmonary hypertension in HIV infection: an outcome determined by particular HLA class II alleles. Am J Respir Crit Care Med. 1996;153(4 Pt 1):1299-301.

49. Itescu S, Rose S, Dwyer E, Winchester R. Certain HLA-DR5 and -DR6 major histocompatibility complex class II alleles are associated with a CD8 lymphocytic host response to human immunodeficiency virus type 1 characterized by low lymphocyte viral strain heterogeneity and slow disease progression. Proc Natl Acad Sci USA. 1994;91(24):11472-6.

50. Mehta NJ, Khan IA, Mehta RN, Sepkowitz DA. HIV-Related pulmonary hypertension: analytic review of 131 cases. Chest. 2000;118(4):1133-41. 
51. Pietra GG, Edwards WD, Kay JM, Rich S, Kernis J, Schloo B, Ayres SM, Bergofsky EH, Brundage BH, Detre KM, et al. Histopathology of primary pulmonary hypertension. A qualitative and quantitative study of pulmonary blood vessels from 58 patients in the National Heart, Lung, and Blood Institute, Primary Pulmonary Hypertension Registry. Circulation. 1989;80(5):1198-206.

52. McLaughlin VV, Archer SL, Badesch DB, Barst RJ, Farber HW, Lindner JR, Mathier MA, McGoon MD, Park MH, Rosenson RS, et al. ACCF/AHA 2009 expert consensus document on pulmonary hypertension a report of the American College of Cardiology Foundation Task Force on Expert Consensus Documents and the American Heart Association developed in collaboration with the American College of Chest Physicians; American Thoracic Society, Inc.; and the Pulmonary Hypertension Association. J Am Coll Cardiol. 2009;53(17):1573-619.

53. Fuso L, Baldi F, Di Perna A. Therapeutic strategies in pulmonary hypertension. Front Pharmacol. 2011;2:21.

54. Pal J, Sen K, Sarkar G, Mandal A, Chakraborty S, Deb A. Effect of antiretroviral therapy on pulmonary hypertension in HIV patients. J Indian Med Assoc. 2013;111(12):845-6.
55. Olalla J, Urdiales D, Pombo M, del Arco A, de la Torre J, Prada JL. Pulmonary hypertension in human immunodeficiency virus-infected patients: the role of antiretroviral therapy. Med Clin. 2014;142(6):248-52.

56. Cicalini S, Chinello P, Grilli E, Petrosillo N. Treatment and outcome of pulmonary arterial hypertension in HIV-infected patients: a review of the literature. Curr HIV Res. 2009;7(6):589-96.

57. Reinsch N, Buhr C, Krings P, Kaelsch H, Kahlert P, Konorza T, Neumann T, Erbel R. Effect of gender and highly active antiretroviral therapy on HIVrelated pulmonary arterial hypertension: results of the HIV-HEART Study. HIV medicine. 2008;9(7):550-6.

58. Zuber JP, Calmy A, Evison JM, Hasse B, Schiffer V, Wagels T, Nuesch R, Magenta L, Ledergerber B, Jenni R, et al. Pulmonary arterial hypertension related to HIV infection: improved hemodynamics and survival associated with antiretroviral therapy. Clin Infect Dis Off Publ Infect Dis Soc Am. 2004;38(8):1178-85.

59. Pugliese A, Isnardi D, Saini A, Scarabelli T, Raddino R, Torre D. Impact of highly active antiretroviral therapy in HIV-positive patients with cardiac involvement. J Infect. 2000;40(3):282-4.

\section{Submit your next manuscript to BioMed Central and take full advantage of:}

- Convenient online submission

- Thorough peer review

- No space constraints or color figure charges

- Immediate publication on acceptance

- Inclusion in PubMed, CAS, Scopus and Google Scholar

- Research which is freely available for redistribution

Submit your manuscript at

www.biomedcentral.com/submit

() Biomed Central 